\title{
Cardio-Protective Effect of Rooibos against Isoproterenol Induced Myocardial Infarction in Male Albino Rats
}

\author{
Reda M.Fekry ${ }^{1}$, Magda K. Ezz ${ }^{2}$, Akaber T. Keshta ${ }^{3}$, Weaam M. Hazem ${ }^{4}$. \\ 1 Assistant Professor of organic chemistry, Chemistry department, Faculty of Science, Zagazig University, Egypt. \\ 2 Assistant Professor of Biochemistry, Biochemistry Department, Faculty of Science, Ain-Shams University, Egypt. \\ 3 Lecture of biochemistry, Chemistry department, Faculty of Science, Zagazig University, Egypt. \\ 4 Biochemistry Division, Chemistry department, Faculty of Science, Zagazig University, Egypt.
}

\begin{tabular}{l}
\hline A R T I C L E I N F O \\
\hline Keywords: \\
Rooibos, oxidative stress, cardio- \\
toxicity, Isoproterenol.
\end{tabular}

\begin{abstract}
A B S T R A C T
Background: Myocardial infarction (MI) is the most lethal manifestation of cardiovascular disease, cause morbidity and mortality in the world. Rooibos (Aspalathus linearis) naturally derived plant, used as a traditional medicine against cardiovascular diseases (CVD). Aim: The present study aims to elucidate whether rooibos possesses cardio-protective effect against MI driven by isoproterenol (ISO). Materials \& Methods: Swiss male adult albino rats were divided into 5 groups: $1^{\text {st }}$ gp served as negative control; $2^{\text {nd }}$ gp served as Rooibos group administrated orally 3 times a week for 8 weeks, $3^{\text {rd }}$ gp served as ISO group injected with $85 \mathrm{mg} / \mathrm{kg} \mathrm{S.C}$. for days 54,$55 ; 4^{\text {th }} \mathrm{gp}$ served as preventive group rooibos administrated then injected with ISO; and $5^{\text {th }}$ gp served as therapeutic group injected with ISO then rooibos administrated. Blood and tissues samples were collected for some biochemical and histopathological studies. Results: Isoproterenol induced MI that characterized by alterations in cardiac markers and functions, enhanced the levels of antioxidant level in heart tissue, and induced myocardial necrosis and inflammation; as these changes were accompanied with elevation of lipid profile except HDL. Our data resulted in Rooibos could ameliorate cardiac injury (aspartate transferase, lactate dehydrogenase, creatine kinase-MB, troponin and Galectin-3), up-regulate antioxidant systems (decreasing MDA and increasing superoxide dismutase, catalase, glutathione reduced, glutathione peroxidase in heart homogenate), and maintain the levels of circulating lipids driven by ISO as well. Rooibos showed significant preventive effects in all the biochemical and histological studies in myocardial infarcted rats rather than therapeutic ones. Conclusions: Rooibos extract may be apparently safe and non-toxic exerts strong favorable cardio-protective action in ISO induced rats due to high antioxidant capacity that decrease the oxidative stress, anti-dyslipidemia, and inhibition of lipid peroxidation.
\end{abstract}

(C) 2014Publisher All rights reserved.

\section{Introduction}

Cardiovascular diseases (CVD) remain the biggest cause of deaths worldwide, though over the last two decades. The etiology of CVD is multifactorial, where a complex combination of environmental, genetic and clinical risk factors seems to play determinant role ${ }^{(1)}$. Myocardial infarction (MI) is the most lethal manifestation of
CVD. MI is the leading cause of morbidity and mortality worldwide, and according to the WHO, it will be the major cause of death in the world by the year $2020^{(2)}$. Isoproterenol (ISO) $\{4-[1-$ hydoxy-2-(1methyl ethyl amino) ethyl] benzene-1, 2 diol\}, a synthetic catecholamine and $\beta$ adrenergic agonist has been shown to cause severe 
stress in the myocardium resulting in infarct like necrosis of the heart muscle ${ }^{(3)}$. The infarction induced by ISO, which arises from a physiological imbalance between free radical production and the cardiac anti-oxidative defense system of experimental animals, is similar to that observed in human MI ${ }^{(4)}$.

High dietary intake of plant foods and beverages linking with a lower incidence of CVD and other chronic diseases may be due to their polyphenolic antioxidant capacity ${ }^{(5)}$. Herbal teas have received much attention in recent years due to their healthpromoting properties, in particular their antioxidant properties ${ }^{(6)}$. Rooibos is an herbal tea made from the leaves and stems of the indigenous South African plant, Aspaluthus linearis (Brum.f) Dahlg. (Family Fabaceae; tribe Crotalarieae) ${ }^{(7)}$. Rooibos is gaining popularity as a health/functional beverage both locally and worldwide (8) due to the natural absence of caffeine and low tannin content ${ }^{(9)}$. Rooibos is a good dietary source of antioxidants containing mostly flavonoids such as flavonols (aspalathin) (10). Studies have reported on the in vivo and invitro antioxidant (11), anti-inflammatory properties (12) as well as the modulation of oxidative stress by Rooibos ${ }^{(5)}$.

Galectin-3 is a new biomarker indicator of CVD; it is a member of a family of proteins comprising soluble $\beta$ galactoside-binding lectin that appears to be a direct mediator of pro-fibrotic pathways and is a potential marker of adverse cardiac remodeling ${ }^{(13)}$. Gal-3 may play a role in the pathophysiology of CVD, through promotion of myocardial fibrosis and inflammation, two related processes involved in myocardial remodeling ${ }^{(14)}$.

The present study is to investigate the cardioprotective effect and therapeutic effects of Rooibos against isoproterenol induced myocardial injury in rats.

\section{MATERIALS AND METHODS}

\section{Plant extraction:}

Rooibos tea: an herbal tea drink made from a woody shrub like leguminous bush stems and leaves of Aspalathus linearis ${ }^{(15)}$. Rooibos aqueous extracts were prepared by the addition of freshly boiled tap water to the tea leaves and stems to a final concentration of $[2 \mathrm{~g} / 100 \mathrm{ml}]$, as used by Beltrán-Debón et al., (16). The mixture was allowed to cool at room temperature for $30 \mathrm{~min}$, filtered (Whatman no. 4) and dispensed into water bottles.

Acute toxicity study: Approximate $\mathrm{LD}_{50}$ of Aqueous extract of Aspalathus linearis (Rooibos tea) in rat were determined according to method OECD 420, ${ }^{(17)}$. The limit dose recommended by human equivalent dose (HED) by the formula $\mathrm{HED}(\mathrm{mg} / \mathrm{kg})=$ Animal $\operatorname{dose}(\mathrm{mg} / \mathrm{kg}) *($ Animal $\mathrm{Km}$ : Human $\mathrm{Km})$ ${ }^{(18)}$. Km was determined from Table (1) ${ }^{(19)}$.

\section{Animals}

Adult male Swiss albino rats weighing (150-200g) were housed in experimental animal house of the Faculty of Science, Zagazig University. The animals were maintained in controlled environment of temperature, humidity, light, and fed on a commercial standard diet and tap water ad libitum.

\section{Chemicals}

Isoproterenol hydrochloride was purchased from Sigma-Aldrich Chemical Co., (St Louis, MO, USA), Troponin $\mathrm{T}$ (TnT) a sandwich EIISA Rat Kit method from (Cloud- Clone Crop), Galectin 3 (Gal-3) a sandwich ELISA Rat Kit method from (BG Medicine, Waltham, MA).

\section{Induction of myocardial infarction}

Isoproterenol was freshly dissolved in sterile saline and subcutaneously (S.C.) injected into the animals at a dose level of $85 \mathrm{mg} / \mathrm{kg}$ b.w. ${ }^{(20)}$.

\section{Experimental design}

40 adult male Swiss albino rats were divided into 5 groups 8 rats/each one as follows: Negative Control group: received sterile saline solution for 8 weeks serving as normal control, Rooibos group: received Rooibos extract orally three times weekly, for 8 consecutive weeks, ISO group: ISO was injected S.C. at an interval of $24 \mathrm{~h}$ on day 54 and 55 of experiment, Preventive Group: received Rooibos extract orally three times weekly for 8 consecutive weeks then injected with ISO at an interval of $24 \mathrm{~h}$ on day 54 and 55, and Therapeutic Group: ISO was S.C. injected at an interval of $24 \mathrm{~h}$ on day $1^{\text {st }}$ and $2^{\text {nd }}$, then received Rooibos extract orally gavaged three times weekly for 8 consecutive weeks. At the end of the experiment animals $\left(56^{\text {th }}\right.$ day), animals were weighed then anaesthetized under light diethyl-ether and dissected. Blood samples and heart tissues were collected for biochemical and histopathological analysis.

\section{(A) Biochemical analysis}


Anti-oxidant assays: The heart homogenate were prepared (0.1g heart tissue $/ 2 \mathrm{ml}$ saline) for different antioxidant assays. Superoxide dismutase (SOD), glutathione peroxidase (GPx), Catalase (CAT) activities, reduced glutathione (GSH), and malondialdhyde (MDA) levels were determined by using Bio-diagnostic kit method according to the method of according to Nishikimi et al., (21), Paglia \&Valentine, ${ }^{(22)}$, Aebi ${ }^{(23)}$, Beutler et al., ${ }^{(24)}$, and Satoh, ${ }^{(25)}$ methods; respectively.

\section{Cardiac Biomarkers measurements:}

Galectin-3 (GAL-3) and Troponin T (TnT) levels were determined by using a sandwich ELISA Rat Kit method in serum according to the method of Christenson et al., (26), and Zhang et al., (27); respectively. AST Kinetic methods according to the Karmen et al., ${ }^{(28)}$ recommendation, Lactate dehydrogenase (LDH) activity was measured through the decrease in NADPH concentration according to Bergmeyer, (29), and CK-MB measured in the presence of an antibody to CK-M monomer according to Wu \& Bowers, ${ }^{(30)}$ method in serum.

\section{Lipid profile measurements:}

Lipid profile (Cholesterol, Triglycerides "TG", and high density lipoprotein-cholesterol (HDL-C), were estimated in serum according Young, ${ }^{(31)}$, Buccolo et al., (32), and Tietz (33) methods; respectively. Low density lipoprotein- cholesterol (LDL-Cholesterol) and very low density lipoprotein-cholesterol (VLDL-cholesterol) were calculated as described by Friedewald $\boldsymbol{e t}$ al., (34) and Atherogenic Index (AI) AI was calculated by the formula: (TC - HDL-C)/HDL-C ${ }^{(35)}$.

\section{(B) Histopathological studies}

Histological evaluation was performed on other portion of the heart tissue. Specimen were fixed in $10 \%$ formalin and embedded in paraffin wax. Heart sections were cut at $5 \mu \mathrm{m}$ in thickness, stained with hematoxylin and eosin (H\&E) and viewed under light microscopy and examined the histological changes according to Lillie, ${ }^{(36)}$.

\section{Statistical analyses}

Data were evaluated by one-way analysis of variance (ANOVA)by "SPSS" 14.0 for Microsoft Windows, SPSS Inc. Chicago USA ${ }^{(37)}$ and considered statistically significant at a two-sided $\mathrm{P}<0.05$. Numerical data were expressed as mean \pm SD.

RESULTS
Rooibos tea was prepared by $(64.35 \mathrm{mg}$ rooibos $/ 30 \mathrm{ml}$ boiled water) then filtrations remain $27 \mathrm{ml}$ filtrate as the extract.

Acute toxicity study: The acute toxicity was estimated by oral administration of the extract to determine the median lethal dose (LD50) of it. Our results revealed that, doses up to $2000 \mathrm{mg} / \mathrm{kg}$ b.w were considered to be safe dose for extract, where no mortality was observed. As the selected dose was $14.3 \mathrm{mg} / \mathrm{kg}$ b.w. is the smaller dose of a rooibos extract produce an effect equal to that produced in human's equivalent to dose $1000 \mathrm{mg}$ per human weight.

\section{Effect of Rooibos tea extract on antioxidants in} heart homogenate in all studied groups:

Table (2) summarized the mean values of MDA, SOD, CAT, GPx and GSH in heart homogenate in all groups. On a hand, the mean value of MDA levels were found to be $23.3 \pm 1.3$, and $18.2 \pm 0.9$ (nmol/g tissue) in negative control group and Rooibos (R.Ex.) group; respectively. ISO (Iso.) group showed a significant increase in MDA levels to be $65.6 \pm 7.0 \quad(\mathrm{nmol} / \mathrm{g}$ tissue $) \quad(\mathrm{p}<0.001)$, compared to negative control group. But, Preventive and Therapeutic groups showed a significant decrease to $22.4 \pm 1.1 \& 39.8 \pm 3.6$ $(\mathrm{nmol} / \mathrm{g}$ tissue) $(\mathrm{p}<0.001)$ respectively; compared to the ISO group. On the other hand; SOD, CAT and GPx activities were decreased from 95.9 \pm 8.4 , $1.1 \pm 0.09$, and $72.1 .0 \pm 4.7$ (U/g tissue) in negative control group to $59.6 \pm 6.3,0.75 \pm 0.13$, and $35.5 \pm 3.3$ in ISO group respectively, $(p<0.001)$. While, their activities were significantly increased to $819.9 \pm 65.6,3.8 \pm 0.68$, and $340.7 \pm 65.3 \&$ to $579.7 \pm 99.1,2.1 \pm 0.27,149.1 \pm 23.5$ in preventive and therapeutic groups; respectively, $(\mathrm{p}<0.001)$ compared to ISO group. Moreover, GSH content was found to be $2.5 \pm 0$ and $2.6 \pm 0.44$ (nmol/g tissue) in negative control group and Rooibos Control (R.Ex.) group, where there was nonsignificant difference between two groups. This content was significantly decreased to be $0.71 \pm 0.13$ in ISO group, $(p<0.001)$. While, in preventive and therapeutic groups, this content was significantly increased to $5.9 \pm 0.99$ and $3.8 \pm 0.34$ respectively, $(\mathrm{p}<0.001)$.

\section{Effect of Rooibos tea extract on heart biomarkers} in all studied groups:

Table (3) summarized the effect of extract on heart function tests in sera of studied groups. 
Measurement of heart enzymes activities demonstrated significant increase in AST, LDH, and CK-MB activities in ISO group to $277.7 \pm 20.8$, $915.0 \pm 106.3$, and 124.6 \pm 7.1 (U/L) respectively compared to negative control group, $(\mathrm{p}<0.001)$. These high activities of heart enzymes were significantly reduced to $116.8 \pm 2.7,396.1 \pm 57.5$, and $55.6 \pm 4.6 \&$ to $198.9 \pm 6.0,640.8 \pm 60.4$, and $82.2 \pm 4.1$ respectively in preventive group and therapeutic group; compared to ISO group $(\mathrm{p}<0.001)$. Also, Troponin and Galactin-3 concentrations were significantly increased in ISO group from $64.5 \pm 4.5$ to $260.7 \pm 8.0(\mathrm{pg} / \mathrm{ml})$, and from $3.7 \pm 0.07$ to $11.3 \pm 0.9(\mathrm{ng} / \mathrm{ml})$; respectively, $(p<0.001)$ compared to negative control group. The troponin and Galctin-3 concentrations were significantly decreased to 201.4 \pm 2.7 , and $186.2 \pm 4.5(\mathrm{pg} / \mathrm{ml}) \&$ to $3.8 \pm 0.19(\mathrm{ng} / \mathrm{ml})$ and $4.2 \pm 0.13$ respectively in preventive group and therapeutic group; compared to ISO group, $(\mathrm{p}<0.001)$.

\section{Effect of Rooibos tea extract on lipid profile in all} studied groups:

Lipid profile (triglycerides "TG", total cholesterol, LDL-cholesterol, HDL-cholesterol, VLDL, and Atherogenic index "AI") were demonstrated in table (4).There was a non-significant difference between negative control group and Rooibos Control (R.Ex.) group, in lipid profile measurements'. TG and total Cholesterol levels were increased in the ISO group to $90.7 \pm 0.88$ $\& 131.0 \pm 3.5(\mathrm{mg} / \mathrm{dl})$; respectively compared to negative control group $60.0 \pm 3.3$ \& $82.2 \pm 1.3$ $(\mathrm{mg} / \mathrm{dl})$ respectively $(\mathrm{p}<0.001)$. Meanwhile, a significant decrease in TG and cholesterol levels to $53.5 \pm 1.6 \& 74.2 \pm 1.4$ and to $62.1 \pm 3.9 \& 87.2 \pm 3.8$, $(\mathrm{p}<0.001)$; respectively in preventive group and therapeutic group compared to ISO group. Moreover, LDL-C, VLDL, and AI were increased from $51.4 \pm 3.0,11.3 \pm 1.2$, and $1.33 \pm 0.148$ in negative control group to $89.5 \pm 3.0,18.6 \pm 0.7$, and $6.71 \pm 0.325$, respectively, in ISO group, $(\mathrm{p}<0.001)$. But, these measurements were significantly decreased by $55.8 \%, 46.8 \%$, and $38.3 \%$ \& by $37.5 \%, 31.2 \%$, and $45.0 \%$; respectively in preventive $\&$ therapeutic groups, $(\mathrm{p}<0.001)$.

Meanwhile, HDL-C was significantly decreased from $35.3 \pm 2.1$ to $16.9 \pm 0.5$ in ISO group, compared to negative control group, $(\mathrm{p}<0.001)$. While, this concentration was increased to $40.8 \pm 2.7$ and to
$30.4 \pm 4.7$; in preventive and therapeutic groups; respectively, $(\mathrm{p}<0.001)$.

\section{Histological studies in all studied groups:}

The histological examinations of heart tissues with Hematoxylin and Eosin stain in the different studied groups confirm the biochemical study in all different groups, as shown in Fig. (1). Negative control Group revealed that, the normal myocardial muscles, exhibited clear integrity of myocardial membrane, Fig (a). Also, Rooibos (R.Ex.) group showed normal heart, as rats showed normal cardiac fibers without any infarction and infiltration of inflammatory cells Fig. (b). However, ISO Group showed disturbance in myocardial muscles. Where, isoproterenol induced of MI. Heart tissues from ISO treated rats showed widespread myocardial structure disorder and subendocardial necrosis with capillary dilatation and leukocyte infiltration. Whereas ISO-induced rats revealed significant myofiber loss, extensive necrosis, infiltration of inflammatory cells, marked myocellular edema and vacuolar degeneration, as shown in Fig. (c). Nevertheless, Rooibos administration induced heart affection either in both therapeutic and preventive groups. As illustrated in Fig. (d), as Rooibos alleviated the ISO induced alterations seen in the above group, reduction of inflammation and re-arrangement of myocardial muscles as normal case, as shown in the preventive group. While, in the therapeutic group, Rooibos administration resulted in mild heart affection, as heart showing congested blood vessel, Fig. (e).

\section{DISCUSSION}

Myocardial infarction (MI) is the leading cause of death all over the world ${ }^{(38)}$. Isoproterenol (ISO) is a synthetic catecholamine and $\beta$-adrenergic receptor agonist represents the most widely used model for MI ${ }^{(39)}$. ISO causes severe stress in the myocardium, resulting in an infarct like necrosis of the heart muscle due to generation of highly cytotoxic free radicals through autoxidation of catecholamine ${ }^{(40)}$. Natural plants play an important role in the modulation of oxidative stress and inflammation and, as a consequence, in the regulation of metabolic pathways and bioenergetics ${ }^{(41)}$. Rooibos, a traditional medicinal plant from South Africa, has been reported to have cardio-protective effects and mitigate metabolic disorders ${ }^{(16)}$. Our results cleared that, aqueous 
extract of rooibos was considered to be safe, where no mortality was observed. So, the use of rooibos as a beverage for everyday consumption has led to a general assumption of its safety as no reports of toxicity. Beltrán-Debón et al., (16) reported that, the consumption of rooibos "natural products", certain beverages containing polyphenols are widely distributed, and they are generally nontoxic and safety.

We studied the effect of Rooibos tea extract on antioxidants (MDA, SOD, CAT, GPx, and GSH) in heart homogenate. On a hand, our results showed that, a significant increase in MDA levels in ISO group by $181.5 \%,(\mathrm{p}<0.001)$, compared to negative control group this results is due to ISO auto-oxidation leads to generation of reactive oxygen species (ROS) that forming peroxyl radicals that attack membranes fatty acids causing a chain reaction of lipid peroxidation expressed as MDA $^{(42)}$. But, preventive and therapeutic groups showed a significant decrease by $65.8 \%$ and $39.3 \%$, $(p<0.001)$ respectively; compared to the ISO group due to rooibos polyphenol high content that inhibit lipid peroxidation (MDA) ${ }^{(43)}$.

Free radical scavenging enzymes such as (SOD, CAT, GPx \& GSH) are the first line cellular defense against oxidative stress, eliminating ROS (44), and preventing the formation of more reactive radical of hydroxyl radical ${ }^{(45)}$. On the other hand, SOD, CAT, GSH, and GPx activities were decreased by $37.8 \%, 31.8 \%, 252.1$, and $50.7 \%$; respectively, $(\mathrm{p}<0.001)$ in ISO group compared to negative control group due to ISO administration induce severe oxidative stress through autooxidation of catecholamines (46) produces quinones, which react with oxygen produce ROS (superoxide anions and hydrogen peroxide), leading to oxidative stress, enzyme inactivation and that lead to make myocardial cell membranes more susceptible to oxidative damage. While, their activities were significantly increased by $1275.6 \%$, $406.7 \%$; $730.9 \%$, and $865.2 \%$ \& by $867.7 \%$, $180.0 \%, 435.2 \%$; and $320.0 \%$ in preventive and therapeutic groups; compared to ISO group, respectively due to rooibos extract contain high polyphenol, in particular flavonoids, flavonols and phenolic acids with potential health benefits as their antioxidant, chelating abilities ${ }^{(47)}$ and increase free radical scavenging enzymes. Our results were in agreement with many authors; Li $\boldsymbol{e t}$ al., ${ }^{(48)}$ reported a significant increase in the levels of lipid peroxidation products (MDA) in ISOinduced rats due to oxidative damage and increased production of free radicals. İlhan et al., ${ }^{(49)}$ demonstrated that, a decrease in SOD and CAT activities in ISO given rats and oxidative stressmediated possible MI. This is due to the fact that excessive superoxide anions may inactivate SOD enzyme, which convert superoxide anion free radicals $\left(\mathrm{O}_{2}{ }^{-}\right)$to $\mathrm{H}_{2} \mathrm{O}_{2}$ and to molecular oxygen ${ }^{(50)}$. Prince \& Roy., ${ }^{(51)}$ found, a significant decline in the concentration of GSH in ISO-induced rats resulted in enhanced lipid peroxidation and lowered activities of heart GPx. Moreover, Hong et al., ${ }^{(52)}$, reported that treatment with Rooibos tea restored the oxidative stress-induced reduction of GSH levels. As, Rooibos tea had an ability to prevent lipid peroxidation, regulated glutathione metabolism, and modulated changes in the activity of SOD and CAT by immobilization stressinduced inhibitory effects on the activities of these anti-oxidative enzymes.

Troponins and cytosolic enzymes such as LDH, AST and CK-MB are localized in the heart myocardium at high concentration, released into blood stream rapidly following myocardial damage ${ }^{(53)}$. Galectin-3 is a novel biomarker used as prognostication, treatment, and therapeutic target in chronic heart failure (HF) ${ }^{(54)}$ and may contribute to the development of HF by mediating progressive alteration of the myocardial extracellular matrix ${ }^{(14)}$. These markers have tissue specificity and catalytic activities are the best markers of MI. Measurement of these markers demonstrated significant increase in AST, LDH, CK-MB, Troponin and Galectin-3 in ISO group by $185.7 \%, 290.5 \%, 109.4 \%, 304.2 \%$, and $205.4 \%$; respectively compared to negative control group, $(\mathrm{p}<0.001)$ due to ISO administration cause cellular damage and loss of functional integrity and /or permeability of cell membrane ${ }^{(55)}$. These high activities of heart markers were significantly reduced by $57.9 \%, 56.7 \%, 55.4 \%, 22.7 \%$ \& $66.4 \%$; and by $28.4 \%, 29.9 \%, 34.0 \%, 28.6 \%$ \& $62.8 \%$; respectively in preventive group and therapeutic group; compared to ISO group ( $\mathrm{p}$ $<0.001$ ). This is due to rooibos high levels content of total polyphenols, in particular flavonoid, with proven antioxidant capacity ${ }^{(5)}$ and beneficial effects on vascular function ${ }^{(56)}$ cause cardio- 
protective competence and maintenance of membrane integrity, thus restricting the leakage of these cardiac markers into circulation.

Many authors were in accordance with our findings, Panda et al., ${ }^{(38)}$ reported increased of $\mathrm{LDH}, \mathrm{CK}-\mathrm{MB}$ and troponin levels in the serum following ISO administration are indicative of cellular damage and loss of functional integrity and/or permeability of cell membrane due to myocardial damage following necrosis in the myocardium (42). Chen et al., (57) found that, increased Galectin-3 was positively associated with the severity of heart failure, that is, Galectin3 levels higher in those with heart failure than that in healthy controls.

In lipid profile measurements, Triglycerides and total Cholesterol levels were increased in the ISO group by $51.2 \%$ \& $59.4 \%$; respectively $(\mathrm{p}<0.001)$ compared to negative control group. Also, LDL-C, VLDL, and AI were increased by $74.1 \%, 64.6 \%$, and $403.8 \%$; respectively, in ISO group compared to negative control group., $(\mathrm{p}<0.001)$. But, HDL-C was significantly decreased from by $52.1 \%$ in ISO group, compared to negative control group, $(p<0.001)$.This is due to ISO elevated circulatory lipids levels (altered lipid metabolism) ${ }^{(56)}$ by increasing cholesterol content due to increased uptake of LDL-C from the blood by myocardial membranes (4), increasing triglycerides due to elevated flux of fatty acids and impaired removal of VLDL from the plasma ${ }^{(59)}$, increasing LDL fraction along with a decrease in HDL-C ${ }^{(60)}$. Meanwhile a significant decrease in TG and cholesterol levels by $69.5 \% \& 43.4 \%$, and by $31.5 \%$ \& $33.4 \% ; \quad(\mathrm{p}<0.001)$; respectively in preventive group and therapeutic group compared to ISO group. But, LDL-C, VLDL, and AI measurements were significantly decreased by $55.8 \%, 46.8 \%$, and $38.3 \%$ \& by $37.5 \%, 31.2 \%$, and $45.0 \%$; respectively in preventive \& therapeutic groups, $(\mathrm{p}<0.001)$. While, HDL-C concentration was increased by $141.4 \%$, and by $79.8 \%$; in preventive and therapeutic groups; respectively, $(\mathrm{p}<0.001)$. Rooibos showed ameliorate lipid profile due to rooibos high content of polyphenols and their antioxidant activity provide protection against oxidative stress conditions; modulate the plasma lipid profile and antioxidant status ${ }^{(5)}$.
Our data were inagreement with, Sharmila\& John, ${ }^{(61)}$ who observed that, an altering plasma lipid profile in ISO-induced rats due to increased levels of plasma triglycerides, decreased number of LDL receptors and high levels of LDL-C, in addition, the decreased levels of HDL makes the heart able to oxidized LDL and cause MI. The increased lipolysis induced by ISO is the reason for increased VLDL-C. Marnewick et al., (5) showed that the dietary intervention with rooibos modulated the serum lipid profile of the participants by significantly decreasing the triglyceride and LDL-C levels and increasing the HDL-C level. Total cholesterol was also lowered, while HDL-C was significantly higher compared to the control.

To confirm our biochemical data, Histopathological study was done. Negative and Rooibos groups revealed normal healthy heart while, ISO induced of MI heart tissues showed widespread myocardial structure disorders and subendocardial necrosis with capillary dilatation and leukocyte infiltration. However, Rooibos administration resulted in heart affection either in both therapeutic and preventive groups. But, Rooibos showed a preventive effect more than therapeutic effect. Therefore, Rooibos has a protective potential role as in MI. Our findings are in accordance with other authors, $\mathbf{L i}$ et al . ${ }^{(48)}$ reported that, histopathological examination of myocardial tissue in control illustrated clear integrity of the myocardial cell membrane where ISO injected rats showed coagulative necrosis, separation of cardiac muscle fibers and infiltration of inflammatory cells.

\section{CONCLUSION:}

In conclusion rooibos extract may be safe and nontoxic, it has a significant effect on the protection of the heart against isoproterenol induced myocardial infarction through maintaining endogenous antioxidant enzyme activities preserving the integrity of membranes, preventing lipid peroxidation. Therefore, Galectin-3 may be a culprit biomarker in heart failure. Daily consumption of rooibos tea may have healthpromoting characteristics and prevents heart disorders without side effects.

\section{REFERENCES}

1. Cooney M.T., Dudina A., D'Agostino R., and Graham I.M., (2010): Cardiovascular risk- 
estimation systems in primary prevention: do they differ? Do they make a difference? Can we see the future? Circulation, 122(3), 300-10.

2. Murugesan M., Revathi R., and Manju V., (2011): Cardio-protective effect of fenugreek on isoproterenol-induced myocardial infarction in rats. Indian J Phcol; 43(5):516-519

3. Rona G., (1985): Catecholamine cardiotoxicity. J. Mol. Cell. Cardiol. 17, 291-306.

4. Anandan R., Mathew S., Sankar T., and Nair P.G.V., (2007): Protective effects of n-3 polyunsaturated fatty acids concentrate on isoproterenol-induced myocardial infarction in rats. ProstaglandinsLeukot.Essent.Fat.Acids.76, $\quad 153-$ 158.

5. Marnewick J.L., Rautenbach F., Venter I., Neethling H., Blackhurst D.M., Wolmarans P., and Macharia M., (2011): Effects of rooibos (Aspalathus linearis) on oxidative stress and biochemical parameters in adults at risk for cardiovascular disease. J. Ethnopharmacol.133, 46-52.

6. Arthur H., Joubert E., De Beer D., Malherbe C.J., and Witthuhn R.C., (2011): Phenylethanoid glycosides as major antioxidants in Lippia multiflora herbal infusion and their stability during steam pasteurization of plant material. Food Chemistry, 127, 581-588.

7. Marnewick J.L., van der Westhuizen F.H., Joubert E., Swanevelder S., Swart P., and Gelderblom W.C.A., (2009): Chemoprotective properties of rooibos (Aspalathus linearis), honeybush (Cyclopia intermedia) herbal and green and black (Camellia sinensis) teas against cancer promotion induced by fumonisin B1 in rat liver. Food and Chemical Toxicology, 47, 220- 229.

8. Joubert E., Gelderblom W.C.A., Louw A., and de Beer D., (2008): South African herbal teas: Aspalathus linearis, Cyclopia spp. and Athrixia phylicoides a review. $J$.

Ethnopharmacol., 119 pp. 376-412.

9. Galasko G.T.F, Furman K.I., and Alberts E., (1989): The caffeine contents of non-alcoholic beverages. Food Chem. Toxicol., 27 pp. 49-51.

10. Shimamura N.T., Miyase. K., Umehara T., Warashina and Fujii S., (2006): Phytoestrogens from Aspalathus linearis. Biol. Pharm. Bull., 29 pp. 1271-1274.

11. Joubert E., Winterton P., Britz T.J. and Ferreira D., (2004): Superoxide anion radical and $\alpha, \alpha$-diphenyl-B-picrylhydrazyl radical scavenging capacity of rooibos (Aspalathus linearis) aqueous extracts, crude phenolic fractions, tannin and flavonoids. Food Res. Int., 37 pp. 133-138.

12. Baba H., Ohtsuka Y., Haruna H., Lee T., Nagata S., Maeda M., Yamashiro Y., and Shimizu T., (2009): Studies of anti-inflammatory effects of Rooibos tea in rats. Pediatr. Int., $51 \mathrm{pp}$. 700-704.

13. Sharma U.C., Pokharel S., van Brakel T.J., van Ber lo J.H., Cleutjens J.P.M., Schroen B., André S., Crijns H.J.G.M., Gabius H.J., Maessen J., and Pinto Y.M., (2004): Galectin-3 marks activated macrophages in failure-prone hypertrophied hearts and contributes to cardiac dysfunction. Circulation; 110:3121-8.

14. Henderson N.C., and Sethi T., (2009): The regulation of inflammation by galectin-3. Immunol Rev; 230: $160-71$.

15. Marnewick J.L., (2009): Rooibos and honeybush: recent advances in chemistry, biologica activity and pharmacological activity and pharmacogynosy. In: Juliana, H.R., Simon, J.E., Ho, C.-T. (Eds.), African Natural Plant Products: New Discoveries and Challenges in Chemistry and Quality. ACS Symposium Series, 1021. Oxford University Press, pp. 277-294.

16. Beltrán-Debón R., Rull A., RodráguezSanabria F., Iswaldi I., Herranzi-Lepez, M., Aragonès G., CampsJ., Alonso-Villaverde C., MenéndezJ.A., Micol V., Segura-Carretero A., and Joven J., (2011): Continuous administration of polyphenols from aqueous rooibos (Aspalathus linearis) extract ameliorates dietary-induced metabolic disturbances in hyperlipidemic mice. Phytomedicine. , 18, 414-424.

17. OECD (1992) Guideline for Testing of Chemicals. No. 420: Acute Oral Toxicity--Fixed Dose Method. Organization for Economic Cooperation and Development, Paris.

18. Reagan-Shaw S., Nihal M., and Ahmad N., (2008): Dose translation from animal to human studies revisited. Faseb J. 2008; 22:659-661.

19. Freireich E.J., et al., (1966): Quantitative comparison of toxicity of anticancer agents in mouse, rat, dog, monkey and man. Cancer Chemother Rep.1966; 50(4):219-244.

20. Rajadurai M., and Prince P.S.M., (2006): preventive effect of naringin on lipids, lipoproteins and lipid metabolic enzymes in isoproterenol- 
induced myocardial infarction in Wister rats. $J$ BiochemMolToxicol ; 20:191-7.

21. Nishikimi M., Appaji N., and Yogi K., (1972): The occurrence of superoxide anion in the reaction of reduced phenazinemethosulfate and molecular oxygen. Biochem. Bioph. Res. Commun46: 849 - 854 .

22. Paglia D.E., and Valentine W.N., (1967): Studies on the quantitative and qualitative characterization of erythrocyte glutathione peroxidase. J. Lab.Clin. Med., 70:158-169.

23. Aebi H., (1984): Catalase in vitro, Methods Enzymol 6:105:121.

24. Beutler E., Duron O., and Kelly B., (1963): Improved method for the determination of blood glutathione. J.Lab. Clin.Med. 61:882-890.

25. Satoh K., (1978): Serum Lipid Peroxide in cerebrovascular disorders determined by a new colorimetric method. Clinica Chimica Acta 90:3743.

26. Christenson R.H., Duh S.H., Wu A.H., Smith A., Abel G., deFilippi C.R., Wang S., Adourian A., Adiletto C., and Gardiner P., ( 2010): Multi-center determination of galectin-3 assay performance characteristics anatomy of a novel assay for use in heart failure. ClinBiochem; 43:683-90.

27. Zhang S., Tang X., Tian J., Li C., Zhang G., Jiang W., and Zhang Z., (2011): Cardioprotective Effect of Sulphonated Formononetin on Acute Myocardial Infarction in Rats. Basic \& Clinical Pharmacology \&Toxicology, 108(6):390-5.

28. Karmen A., Wroblewski F., and Ladue J.S., (1955): Transaminase activity in human blood. $J$. Clin. Invest 34:126-31.

29. Bergmeyer H.U., (1963): Methods of enzymatic analysis. New York: Academic Press, 1963; 1-1063.

30. Wu A.H.B. and Bowers C.N. Jr, (1982): Evaluation and comparison of immune-inhibition and immune-precipitation methods for differentiating $\mathrm{MB}$ from $\mathrm{BB}$ and macro forms of creatine kinase isoenzymes in patients and healthy individuals. ClinChem: 2017.

31. Young DS., (1990): Effects of on Clinical Laboratory tests, $3^{\text {rd }}$ ed. 3:6-12.

32. Buccolo G., et al., (1973): Quantitative determination of serum triglycerides by use of enzymes. Clin. Chem., 19(5): 476-482.
33. Tietz N.W., (1976): Fundamentals of Clinical Chemistry W. B. Saunders C., Philadelphia.

34. Friedewald W.T., Levy R.I., and Fredrickson D.S., (1972): Estimation of concentration of LDL-Cholesterol in plasma, without use of preparative ultracentrifuge. Clin. Chem., 18: 499-50.

35. Matsubara M., Maruoka S., and Katayose S., (2002): Decreased Plasma Adiponectin Concentrations in Women with Dyslipidemia. $J$ Clin Endocrinol Metab, , 87(6):2764-2769

36. Lillie R.D., (1976): Histopathologic technique. Practical histochemistry. 95: 851-859.

37. Levesque R., (2007): Programming and Data Management: A Guide for SPSS and SAS Users, Fourth Edition, SPSS Inc., Chicago Ill.

38. Panda S., Kar A., and Ramamurthy V., (2014): Cardioprotective effect of vincristine on isoproterenol-induced myocardial necrosis in rats .European Journal of Pharmacology723; 451-458.

39. Li Y., Shen D., Tang X., Li X., Wo D., Yan H., Song R., Feng J., Li P., Zhang J., and Li J., (2014):Chlorogenic acid prevents isoproterenolinduced hypertrophy inneonatal rat myocytes .Toxicology Letters 226 (2014) 257-263.

40. Selvaraj P., and Pugalendi K.V., (2012): Efficacy of hesperidin on plasma, heart and liver tissue lipids in rats subjected to isoproterenolinduced cardiotoxicity. Exp. Toxicol. Pathol. , 64, 449-452.

41. Joven J., Rull A., Rodriguez-Gallego E., Camps J., Riera-Borrull M., HernJndezAguilera A., Martin-Paredero V., SeguraCarretero A., Micol V., Alonso-Villaverde C., and Menéndez J.A., (2013): Multifunctional targets of dietary polyphenols in disease: A case for the chemokine network and energy metabolism. Food and Chemical Toxicology 51; 267-279.

42. Priscilla D.H., and Prince P.S., (2009): Cardioprotective effect of gallic acid on cardiac troponin-T, cardiac marker enzymes, lipid peroxidation products and antioxidants in experimentally induced myocardial infarction in Wistar rats. Chemico-Biol. Interact.179, 118-124.

43. Marnewick J., Joubert E., Joseph S., Swanevelder S., Swart P. and Gelderblom W.C.A. (2005): Inhibition of tumour promotion in mouse skin by extracts of rooibos (Aspalathus linearis) and Honeybush (Cyclopia intermedia), 
unique South African herbal teas. Cancer Letters, 224,193-202.

44. Karthikeyan K., SaralaBai B.R, Gauthaman K., and Devaraj S.N., (2005): Protective effect of propyl gallate against myocardial oxidative stress-induced injury in rats. J Pharm Pharmacol; 57:67-73.

45. Wu J., Hecker J.G., and Chiamvimonvat N., (2009): Antioxidant enzyme gene transfer for ischemic diseases. Adv Drug Deliver Rev 61:351363.

46. Remiao F., Carmo H.,Carvahlo F., and Bastos M.L., (2001):Copper enhances isoproterenol toxicity in isolated rat cardiomyocytes : effects on oxidative stress. Cardiovasc.Toxicol.1, 195-204.

47. Tammela P., Laitinen L., Galkin A., Wennberg T., Heczko R., Vuorela H., Slotte J.P., and Vuorela P., (2004): Permeability characteristics and membrane affinity of flavonoids and alkyl gallates in Caco-2 cells and in phospholipids vesicles. Archives of Biochemistry and Biophysics 425: 193-199.

48. Li Hua., Xie Yan-Hua., Yang Qian., Wang Si-Wang ., Zhang Bang-Le., Wang Jian-Bo., Cao Wei., Bi Lin- Lin., Sun Ji-Yuan., Miao Shan., Hu Jing., Zhou Xuan-Xuan., and QiuPeng Cheng.,(2012): Cardioprotective Effect of Paeonol and Danshensu Combination on Isoproterenol-Induced Myocardial Injury in Rats. PLOS ONE | November 2012 | Volume 7| Issue 11 | $e 48872$.

49. İlhan S., Yılmaz N., Nacar E., Motor S., Oktar S., and Şahna E., (2014): The effect of caffeic acid phenethyl ester on isoproterenolinduced myocardial injury in hypertensive rats. AnadoluKardiyolDerg; 14(0): 4825.

50. Panda V.S., and Naik S.R., (2008): Cardioprotective activity of ginkgo biloba phytosomes in isoproterenol-induced myocardial necrosis in rats: a biochemical and histoarchitectural evaluation. Exp ToxicolPathol; 60: 397-404.

51. Prince S.M.P., and Roy A.J., (2013): pCoumaric acid attenuates apoptosis in isoproterenol-induced myocardial infarcted rats by inhibiting oxidative stress International Journal of Cardiology 168; 3259-3266.

52. Hong In-Sun., Lee Hwa-Yong., and Kim3 Hyun-Pyo., (2014): Anti-Oxidative Effects of
Rooibos Tea (Aspalathus linearis) on Immobilization-Induced Oxidative Stress Rat Brain. PLOS ONE | Volume 9| Issue 1| e87061.

53. Queenthy S.S., and John B., (2013): Diosmin exhibits anti-hyperlipidemic effects in isoproterenol induced myocardial infarcted rats. European Journal of Pharmacology 718(2013)213-218.

54. Fayed H.M., Alsenbesy M.A., Saleem T.H, and Ahmed M.A., (2013): Comparative Study of Circulating Cardiac Biomarker Galectin-3 and Troponin I in Heart Failure Patients. Clinical Medicine and Diagnostics 3(4): 92-100 DOI: 10.5923/j.cmd. 0304.04.

55. Sabeena F.K.H., Anandan R., Kumar S.H., Shiny K.S., Sankar T.V., and Tkankappan T.K ., (2004) : Effect of squalene on tissue defense system in isoproterenol-induc myocardia linfarction in rats. Pharmacol.Res.50, 231-236.

56. Pantsi W.G., Marnewick J.L., Esterhuyse A.J., Rautenbach F., and van Rooyen J., (2011): Rooibos (Aspalathus linearis) offers cardiac protection against ischaemia/reperfusion in the isolated perfused rat heart. Phytomedicine18; $1220-1228$.

57. Chen K., Jiang R.J., Wang C.Q., Yin Z.F., Fan Y.Q., Cao J.T., Han Z.H., Wang Y., and Song D.Q.,(2013a):Predictive value of plasma galectin-3 in patients with chronic heart failure. European Review for Medical and Pharmacological Sciences ; 17: 1005-1011

58. Zeller M., Masson D., Farnier M., Lorgis L., Deckert V., de Barros J.P.P., Desrumaux C., Sicard P., Grober J., Blache D., Gambert P., Rochette L., PHARMD., Cottin Y., and Lagrost L., (2007): High serum cholesteryl ester transfer rates and small high-density lipoproteins

59. Prince S.M.P., and Sathya B., (2010): Pretreatment with quercetin ameliorates lipids, lipoproteins and marker enzymes of lipid metabolism in isoproterenol treated cardiotoxic male Wistar rats. Eur. J. Pharmacol. 635, 142148.

60. Karthikeyan K., Bai B.R.S., and Devaraj S.N., (2007): Efficacy of grape seed proanthocyanidins on serum and heart tissue lipids in rats subjected to isoproterenol-induced myocardial injury. Vascul. Pharmacol. 47, 295301. 
61. Sharmila Q. S., and John B., (2013): isoproterenol induced myocardial infarcted rats. Diosmin exhibits anti- hyperlipidemic effects in European JournalofPharmacology718;213-218.

Table (1): Table (1). Representative Surface Area to Weight Ratios, [km] for Various Species:

\begin{tabular}{|lccc|}
\hline Species & Body Weight [kg] & Body Surface Area [sq.m.] & km factor \\
\hline Mouse & 0.02 & 0.0066 & 3.0 \\
Rat & 0.15 & 0.025 & 5.9 \\
Monkey & 3.0 & 0.24 & 12 \\
Dog & 8.0 & 0.40 & 20 \\
Human, Child & 20 & 0.80 & 25 \\
Human, Adult & 60 & 1.6 & 37 \\
\hline
\end{tabular}

Table (2): Heart Biomarkers in all studied groups:

\begin{tabular}{|c|c|c|c|c|c|c|c|c|c|c|}
\hline \multirow[b]{2}{*}{ Variables } & \multicolumn{2}{|c|}{$\begin{array}{c}\text { Negative control } \\
\text { group }\end{array}$} & \multicolumn{2}{|c|}{$\begin{array}{c}\text { Rooibos Control (R.Ex.) } \\
\text { group" }\end{array}$} & \multicolumn{2}{|c|}{ ISO Control (Iso.) Group } & \multicolumn{2}{|c|}{$\begin{array}{l}\text { Preventive Group } \\
\text { (Iso + R.Ex.) }\end{array}$} & \multicolumn{2}{|c|}{$\begin{array}{c}\text { Therapeutic Group } \\
\text { (R.Ex+ Iso.) }\end{array}$} \\
\hline & $\begin{array}{l}\text { Mean } \pm \\
\text { SD. }\end{array}$ & $\begin{array}{c}\% \\
\text { Change }\end{array}$ & $\begin{array}{l}\text { Mean } \pm \\
\text { SD. }\end{array}$ & $\begin{array}{c}\% \\
\text { Change }\end{array}$ & Mean \pm SD. & $\begin{array}{c}\% \\
\text { Change }\end{array}$ & Mean \pm SD. & $\begin{array}{c}\% \\
\text { Change }\end{array}$ & Mean \pm SD. & $\begin{array}{c}\% \\
\text { Change }\end{array}$ \\
\hline $\begin{array}{l}\operatorname{AST}(\mathbf{U} / \\
\mathrm{L})\end{array}$ & $97.2 \pm 3.9$ & ------- & $82.3 \pm 2.3$ & $-15.3 \%$ & $\begin{array}{c}277.7 \pm 20.8 \\
* * *\end{array}$ & $185.7 \%$ & $\begin{array}{c}116.8 \pm 2.7 \\
* * *\end{array}$ & $-57.9 \%$ & $\begin{array}{c}198.9 \pm 6.0 \\
* * *\end{array}$ & $-28.4 \%$ \\
\hline $\begin{array}{l}\mathbf{L D H}(\mathbf{U} / \\
\mathbf{L )}\end{array}$ & $234.3 \pm 17.1$ & ------- & $240.1 \pm 6.2$ & $2.4 \%$ & $\begin{array}{c}915.0 \pm 106.3 \\
* * *\end{array}$ & $290.5 \%$ & $\begin{array}{c}396.1 \pm 57.5 \\
* * *\end{array}$ & $-56.7 \%$ & $\begin{array}{c}640.8 \pm 60.4 \\
* * *\end{array}$ & $-29.9 \%$ \\
\hline $\begin{array}{c}\text { CK-MB } \\
(\mathbf{U} / \mathbf{L})\end{array}$ & $59.5 \pm 2.0$ & ------ & $64.5 \pm 0.9$ & $8.4 \%$ & $\begin{array}{l}124.6 \pm 7.1 \\
* * *\end{array}$ & $109.4 \%$ & $\begin{array}{c}55.6 \pm 4.6 \\
* * *\end{array}$ & $-55.4 \%$ & $\begin{array}{l}82.2 \pm 4.1 \\
* * *\end{array}$ & $-34.0 \%$ \\
\hline $\begin{array}{l}\text { Troponi } \\
\mathbf{n} \\
(\mathrm{pg} / \mathrm{ml})\end{array}$ & $64.5 \pm 4.5$ & ------- & $54.7 \pm 2.9$ & $-15.2 \%$ & $\begin{array}{l}260.7 \pm 8.0 \\
\quad * * *\end{array}$ & $304.2 \%$ & $\begin{array}{l}201.4 \pm 2.7 \\
* * *\end{array}$ & $-22.7 \%$ & $\begin{array}{l}186.2 \pm 4.5 \\
* * *\end{array}$ & $-28.6 \%$ \\
\hline $\begin{array}{c}\text { Galctin- } \\
\mathbf{3} \\
(\mathrm{ng} / \mathrm{ml})\end{array}$ & $3.7 \pm 0.07$ & ------- & $3.6 \pm 0.05$ & $-2.7 \%$ & $\begin{array}{l}11.3 \pm 0.9 \\
* * *\end{array}$ & $205.4 \%$ & $\begin{array}{l}3.8 \pm 0.19 \\
* * *\end{array}$ & $-66.4 \%$ & $\begin{array}{l}4.2 \pm 0.13 \\
* * *\end{array}$ & $-62.8 \%$ \\
\hline
\end{tabular}

Significant difference at $(* \mathrm{P}<0.05, * * \mathrm{P}<0.01, * * * \mathrm{P}<0.001)$

Table (3): Non-enzymatic and Enzymatic anti-oxidants in all studied groups:

\begin{tabular}{|c|c|c|c|c|c|c|c|c|c|c|}
\hline \multirow[t]{2}{*}{ Variables } & \multicolumn{2}{|c|}{$\begin{array}{c}\text { Negative control } \\
\text { group }\end{array}$} & \multicolumn{2}{|c|}{$\begin{array}{c}\text { Rooibos Control (R.Ex.) } \\
\text { group" }\end{array}$} & \multicolumn{2}{|c|}{ ISO Control (Iso.) Group } & \multicolumn{2}{|c|}{$\begin{array}{c}\text { Preventive Group } \\
\text { (Iso + R.Ex.) }\end{array}$} & \multicolumn{2}{|c|}{$\begin{array}{c}\text { Therapeutic Group } \\
(\text { R.Ex+ Iso.) }\end{array}$} \\
\hline & $\begin{array}{l}\text { Mean } \pm \\
\text { SD. }\end{array}$ & $\begin{array}{c}\% \\
\text { Change }\end{array}$ & $\begin{array}{l}\text { Mean } \\
\pm \text { SD. }\end{array}$ & $\begin{array}{c}\% \\
\text { Change }\end{array}$ & Mean \pm SD. & $\begin{array}{c}\% \\
\text { Change }\end{array}$ & $\begin{array}{l}\text { Mean } \\
\pm \text { SD. }\end{array}$ & $\begin{array}{c}\% \\
\text { Change }\end{array}$ & $\begin{array}{l}\text { Mean } \pm \\
\text { SD. }\end{array}$ & $\begin{array}{c}\% \\
\text { Change }\end{array}$ \\
\hline $\begin{array}{c}\text { MDA } \\
\text { (nmol/g } \\
\text { tissue) }\end{array}$ & $23.3 \pm 1.3$ & ------- & $18.2 \pm 0.9$ & $-21.8 \%$ & $\begin{array}{l}65.6 \pm 7.0 \\
* * *\end{array}$ & $181.5 \%$ & $\begin{array}{l}22.4 \pm 1.1 \\
\quad * * *\end{array}$ & $-65.8 \%$ & $\begin{array}{l}39.8 \pm 3.6 \\
* * *\end{array}$ & $-39.3 \%$ \\
\hline $\begin{array}{l}\text { SOD }(U / \\
\text { g tissue })\end{array}$ & $\begin{array}{c}95.9 \pm 8 \\
4\end{array}$ & ------ & $\begin{array}{l}141.5 \\
\pm 23.7\end{array}$ & $47.5 \%$ & $\begin{array}{l}59.6 \pm 6.3 \\
* * *\end{array}$ & $-37.8 \%$ & $\begin{array}{c}819.9 \pm 65.6 \\
* * *\end{array}$ & $1275.6 \%$ & $\begin{array}{l}579.7 \pm 99.1 \\
* * *\end{array}$ & $867.7 \%$ \\
\hline $\begin{array}{l}\text { CAT (U/ } \\
\text { g tissue) }\end{array}$ & $1.1 \pm 0.09$ & ------- & $1.6 \pm 0.2$ & $45.5 \%$ & $\begin{array}{c}0.75 \pm 0.13 \\
* * *\end{array}$ & $-31.8 \%$ & $\begin{array}{l}3.8 \pm 0.68 \\
* * *\end{array}$ & $406.7 \%$ & $\begin{array}{c}2.1 \pm 0.27 \\
* * *\end{array}$ & $180.0 \%$ \\
\hline $\begin{array}{l}\text { GPx }(U / g \\
\text { tissue })\end{array}$ & $72.1 \pm 4.7$ & ------ & $87.5 \pm 5.8$ & $21.4 \%$ & $\begin{array}{l}35.5 \pm 3.3 \\
* * *\end{array}$ & $-50.7 \%$ & $\begin{array}{c}340.7 \pm 65.3 \\
* * *\end{array}$ & $865.2 \%$ & $\begin{array}{c}149.1 \pm 23.5 \\
* * *\end{array}$ & $320.0 \%$ \\
\hline $\begin{array}{l}\text { GSH } \\
\text { (nmol/g } \\
\text { tissue) }\end{array}$ & $2.5 \pm 0.4$ & ------ & $2.6 \pm 0.4$ & $4.0 \%$ & $\begin{array}{l}0.71 \pm 0.13 \\
* * *\end{array}$ & $-252.1 \%$ & $\begin{array}{l}5.9 \pm 0.99 \\
* * *\end{array}$ & $730.9 \%$ & $\begin{array}{l}3.8 \pm 0.34 \\
\quad * * *\end{array}$ & $435.2 \%$ \\
\hline
\end{tabular}

Significant difference at $(* \mathbf{P}<0.05, * * \mathbf{P}<0.01, * * * \mathbf{P}<0.001)$ 
Table (4): Lipid profile in all studied groups:

\begin{tabular}{|c|c|c|c|c|c|c|c|c|c|c|}
\hline \multirow[t]{2}{*}{ Variables } & \multicolumn{2}{|c|}{ Negative control group } & \multicolumn{2}{|c|}{$\begin{array}{l}\text { Rooibos Control } \\
\text { (R.Ex.) group" }\end{array}$} & \multicolumn{2}{|c|}{$\begin{array}{c}\text { ISO Control (Iso.) } \\
\text { Group }\end{array}$} & \multicolumn{2}{|c|}{$\begin{array}{c}\text { Preventive Group } \\
\text { (Iso + R.Ex.) }\end{array}$} & \multicolumn{2}{|c|}{$\begin{array}{c}\text { Therapeutic Group } \\
\text { (R.Ex+ Iso.) }\end{array}$} \\
\hline & $\begin{array}{l}\text { Mean } \pm \\
\text { SD. }\end{array}$ & $\begin{array}{c}\% \\
\text { Change }\end{array}$ & $\begin{array}{l}\text { Mean } \pm \\
\text { SD. }\end{array}$ & $\begin{array}{c}\% \\
\text { Change }\end{array}$ & Mean \pm SD. & $\begin{array}{c}\% \\
\text { Change }\end{array}$ & $\begin{array}{l}\text { Mean } \pm \\
\text { SD. }\end{array}$ & $\begin{array}{c}\% \\
\text { Change }\end{array}$ & $\begin{array}{l}\text { Mean } \pm \\
\text { SD. }\end{array}$ & $\begin{array}{c}\% \\
\text { Change }\end{array}$ \\
\hline TG (mgdl) & $60.0 \pm 3.3$ & ------- & $52.0 \pm 0.7$ & $-13.3 \%$ & $90.7_{* *}^{ \pm 0.88}$ & $51.2 \%$ & $53.5 \pm 1.6$ & $-69.5 \%$ & $62.1 \pm 3.9$ & $-31.5 \%$ \\
\hline $\begin{array}{c}\text { Cholesterol } \\
\text { (mg/dl) }\end{array}$ & $82.2 \pm 1.3$ & ------ & $85.2 \pm 1.9$ & $3.6 \%$ & $131.0 \pm 3.5$ & $59.4 \%$ & $74.2 \pm 1.4$ & $-43.4 \%$ & $87.2 \pm 3.8$ & $-33.4 \%$ \\
\hline $\begin{array}{l}\text { LDL-C } \\
(\mathrm{mg} / \mathrm{dl})\end{array}$ & $51.4 \pm 3.0$ & ------- & $48.8 \pm 4.4$ & $-5.1 \%$ & $89.5 \pm 3.0$ & $74.1 \%$ & $39.5 \pm 5.0$ & $-55.8 \%$ & $55.9 \pm 42.6$ & $-37.5 \%$ \\
\hline $\begin{array}{l}\text { HDL-C } \\
(\mathrm{mg} / \mathrm{dl})\end{array}$ & $35.3 \pm 2.1$ & ------ & $37.0 \pm 1.7$ & $4.8 \%$ & $16.9 \pm 0.5$ & $-52.1 \%$ & $40.8 \pm 2.7$ & $141.4 \%$ & $30.4 \pm 4.7$ & $79.8 \%$ \\
\hline $\begin{array}{l}\text { VLDL } \\
(\mathrm{mg} / \mathrm{dl})\end{array}$ & $11.3 \pm 1.2$ & ------- & $10.2 \pm 0.3$ & $-9.7 \%$ & $18.6 \pm 0.7$ & $64.6 \%$ & $9.9 \pm 0.6$ & $-46.8 \%$ & $12.8 \pm 01.0$ & $-31.2 \%$ \\
\hline AI & $1.33 \pm 0.148$ & ------ & $1.30 \pm 0.125$ & $-2.25 \%$ & $6.71 \pm 0.325^{* * *}$ & $403.8 \%$ & $0.82 \pm 0.094$ & $-38.3 \%$ & $1.93 \pm 0.486$ & $-45.0 \%$ \\
\hline
\end{tabular}

Significant difference at $(* \mathbf{P}<0.05, * * \mathbf{P}<0.01, * * * \mathbf{P}<0.001)$
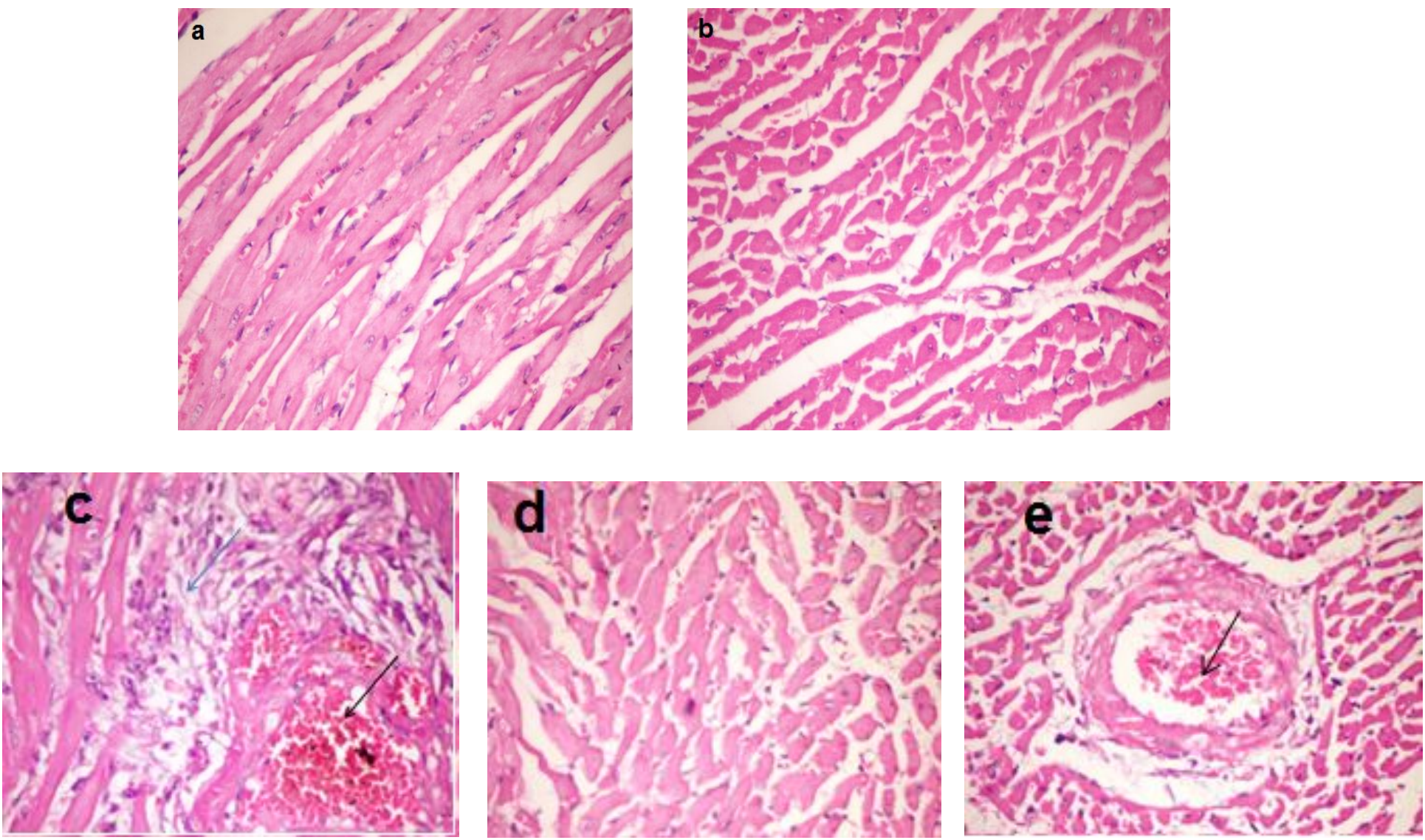

Fig. (1)The histological examinations of heart tissues in all studied groups, (H\&E X 400).

(a): A photograph of Negative Control Group: Heart with normal myocardial muscles.

(b): A photograph of Rooibos (R.Ex.) group Heart apparently healthy myocardial muscles.

(c): A photograph of $\mathbf{I S O}$ group Heart with muscular hyalinosis, hemorrhagic areas (black arrow), and infiltration of mononuclear cells (blue arrow).

(d): A photograph of Preventive group Heart apparently normal myocardial muscles.

(e): A photograph of Therapeutic group Heart with congested blood vessel (arrow). 